\title{
Challenges in the Role of Gammaglobulin Replacement Therapy and Vaccination Strategies for Hematological Malignancy
}

\author{
Silvia Sánchez-Ramón ${ }^{1,2 *}$, Fatima Dhalla ${ }^{3,4}$ and Helen Chape/3,4* \\ ${ }^{1}$ Department of Clinical Immunology and IdISSC, Hospital Clínico San Carlos, Madrid, Spain, ${ }^{2}$ Department of Microbiology I, \\ Complutense University School of Medicine, Madrid, Spain, ${ }^{3}$ Nuffield Department of Medicine, University of Oxford, Oxford, \\ UK, ${ }^{4}$ Department of Clinical Immunology, John Radcliffe Hospital, Headington, Oxford, UK
}

OPEN ACCESS

Edited by: Matteo Bellone, San Raffaele Hospital, Italy

Reviewed by: Jagadeesh Bayry,

French Institute of Health and Medical Research, France Amorette Barber, Longwood University, USA Lydia Scarfò, San Raffaele Hospital, Italy

*Correspondence:

Silvia Sánchez-Ramón ssramon@salud.madrid.org; Helen Chapel

helen.chapel@ndm.ox.ac.uk

Specialty section: This article was submitted to Cancer Immunity and Immunotherapy,

a section of the journal

Frontiers in Immunology

Received: 27 May 2016 Accepted: 05 August 2016 Published: 22 August 2016

Citation:

Sánchez-Ramón S, Dhalla F and Chapel H (2016) Challenges in the Role of Gammaglobulin Replacement Therapy and Vaccination Strategies for Hematological Malignancy.

Front. Immunol. 7:317. doi: 10.3389/fimmu.2016.00317
Patients with chronic lymphocytic leukemia (CLL) and multiple myeloma (MM) are prone to present with antibody production deficits associated with recurrent or severe bacterial infections that might benefit from human immunoglobulin (lg) (IVIg/SClg) replacement therapy. However, the original IVIg trial data were done before modern therapies were available, and the current indications do not take into account the shift in the immune situation of current treatment combinations and changes in the spectrum of infections. Besides, patients affected by other B cell malignancies present with similar immunodeficiency and manifestations while they are not covered by the current IVlg indications. A potential beneficial strategy could be to vaccinate patients at monoclonal B lymphocytosis and monoclonal gammopathy of undetermined significance stages (for CLL and $\mathrm{MM}$, respectively) or at B-cell malignancy diagnosis, when better antibody responses are attained. We have to re-emphasize the need for assessing and monitoring specific antibody responses; these are warranted to select adequately those patients for whom early intervention with prophylactic anti-infective therapy and/or IVIg is preferred. This review provides an overview of the current scenario, with a focus on prevention of infection in patients with hematological malignancies and the role of Ig replacement therapy.

Keywords: antibody production defect, hypogammaglobulinemia, chronic lymphocytic leukemia, hematological malignancy, multiple myeloma, replacement immunoglobulins

\section{INTRODUCTION}

Patients affected by hematological malignancy, in particular chronic lymphocytic leukemia (CLL) and multiple myeloma (MM), were recognized as presenting antibody production deficits many years ago $(1,2)$, and the proposal was made that they might benefit from antibody replacement therapy (3). Landmark clinical trials in CLL and MM in the late 1980s and early 1990s settled the basis for the current indications of intravenous immunoglobulins (IVIg) in hematological malignancies associated with severe secondary hypogammaglobulinemia and recurrent infections (4-6). In recent years, the convergence of better immunological evaluation of antibody responses for the selection of patients who might benefit from immunoglobulin replacement therapy, together with substantially improved therapies for these malignant conditions that lengthen survival, has prompted the need to review the role of IVIg (or subcutaneous administration, SCIg) in the 
prevention of infectious complications. Besides, there are other $\mathrm{B}$ cell malignancies with similar immune defects that are not currently authorized as indications for IVIg, thus resulting in subsequent discrimination of such patients.

\section{Outline of Article}

First, we briefly review the current evidence for the immunological approach to the prevention of infectious complications associated with defective antibody responses in CLL and MM. We then survey the current challenges derived from the improvements in diagnosis and therapy of hematological malignancies and discuss some practical issues. Finally, we consider the potential indices for better selection of patients most likely to benefit from early intervention with IVIg or SCIg.

\section{CURRENT EVIDENCE-BASED GUIDELINES FOR IMMUNOGLOBULIN THERAPY IN HEMATOLOGICAL MALIGNANCIES}

Recurrent or severe infections are a major cause of morbidity and mortality in patients with CLL (between 30 and 50\% of deaths) (7-9) and MM (22\% of deaths in the first year after diagnosis) (10), especially in patients with renal failure (11).

Hypogammaglobulinemia (low serum levels of IgG and IgA with variable $\operatorname{IgM}$ ) is a well-recognized complication associated with hematological malignancy, most commonly in CLL and
$\mathrm{MM}$, while not common at diagnosis and during the natural history of other B cell malignancies (12). It is present in about a $25 \%$ of patients at diagnosis and up to $85 \%$ during the disease course, rendering them susceptible to infections $(7,9,13,14)$. It occurs in patients with mutated and unmutated immunoglobulin heavy chain (IGHV) genes (7). Nevertheless, other immune defects are present in these patients mostly due to the underlying disease and to chemotherapeutic protocols, namely neutropenia, mucosal lesions, T-lymphocyte dysregulation and altered cytokine secretion profiles, complement activation (15-17), NK cell dysfunction (18), phagocytic alterations $(19,20)$, as well as the elderly age of such patients and their poor functional status $(7,21-23)$.

Complex causes of these low immunoglobulin levels (Igs) include defective production of polyclonal Igs due to abnormal function of non-clonal $\mathrm{CD}^{-} \mathrm{B}$ cells; impaired $\mathrm{IgG}$ and $\operatorname{IgA}$ class-switch through abnormal CD40-CD40L interaction and down-modulation of CD40L $(24,25)$; impaired help and excessive suppression by T-cells $(26,27)$; sequestration of T-cell help by CLL cells in pseudofolicles (7), inhibition of CD95 $5^{+}$plasma cells in the bone marrow via interaction with CD95L on CLL B-cells (28), and iatrogenic myelosuppressive chemotherapy $(9,21)$.

Data from six randomized clinical trials in CLL and one with MM patients with hypogammaglobulinemia and history of infections demonstrated that IVIg significantly decreased the rate of bacterial infections and prolonged the time to first infection, with no differences in non-bacterial infections (Table 1). These trials suggested that the best dosing was $400 \mathrm{mg} / \mathrm{kg} / 3$ weeks until steady state is reached, followed by $400 \mathrm{mg} / \mathrm{kg} / 5$ weeks (grade

TABLE 1 | Clinical trials to determine effectiveness and dosage of replacement intravenous immunoglobulin in hematological malignancy [adapted from Dhalla et al. (9)].

\begin{tabular}{|c|c|c|c|}
\hline Publication & Target population & Study description & Relevant results \\
\hline $\begin{array}{l}\text { Cooperative } \\
\text { Group (4) }\end{array}$ & $\begin{array}{l}\text { CLL patients (81) with } \\
\text { hypogammaglobulinemia or } \\
\text { serious infections }\end{array}$ & $\begin{array}{l}\text { Multicenter controlled, randomized double-blind, IVlg } \\
400 \mathrm{mg} / \mathrm{kg} / 21 \text { days versus placebo for } 12 \text { months }\end{array}$ & $\begin{array}{l}\text { Fewer major and moderate bacterial infections overall } \\
\text { Longer period to first serious bacterial infection } \\
\text { No differences in viral and fungal infections }\end{array}$ \\
\hline $\begin{array}{l}\text { Griffiths } \\
\text { et al. (29) }\end{array}$ & $\begin{array}{l}\mathrm{CLL}(8) \text { and low grade } \\
\mathrm{NHL}(4) \text { patients with } \\
\text { hypogammaglobulinemia or } \\
\text { serious infections }\end{array}$ & $\begin{array}{l}\text { Double-blind, randomized crossover IVlg } 400 \text { mg/ } \\
\mathrm{kg} / 21 \text { days versus placebo for } 12 \text { months then } \\
\text { changed to the alternative drug }\end{array}$ & $\begin{array}{l}\text { Fewer major and moderate bacterial infections overall } \\
\text { Serious bacterial infection showed a growing trend with } \\
\operatorname{lgG}<6.4 \mathrm{~g} / \mathrm{L} \\
\text { No differences in trivial infections }\end{array}$ \\
\hline $\begin{array}{l}\text { Chapel et al. } \\
\text { (31) }\end{array}$ & $\begin{array}{l}\text { MM patients (83) with } \\
\text { hypogammaglobulinemia or } \\
\text { infections }\end{array}$ & $\begin{array}{l}\text { Double-blind, randomized IVlg } 400 \text { mg/kg/21 days } \\
\text { versus placebo }\end{array}$ & $\begin{array}{l}\text { Fewer life-threatening and severe and recurrent infections } \\
\text { Maximum benefit in patients with poor pneumococcal } \\
\text { response }\end{array}$ \\
\hline $\begin{array}{l}\text { Chapel et al. } \\
\text { (5) }\end{array}$ & $\begin{array}{l}\text { CLL patients (34) with } \\
\text { hypogammaglobulinemia and } \\
\text { infections }\end{array}$ & $\begin{array}{l}\text { Double-blind, randomized IVlg at either } 500 \text { or } \\
250 \mathrm{mg} / \mathrm{kg} / 28 \text { days }\end{array}$ & Similar rates of infection \\
\hline $\begin{array}{l}\text { Jurlander } \\
\text { et al. (32) }\end{array}$ & $\begin{array}{l}\text { CLL patients (15) with } \\
\text { hypogammaglobulinemia and } \\
\text { recurrent infections }\end{array}$ & Open label IVlg 1,000 mg/21 days & $\begin{array}{l}\text { Fewer hospital admissions and febrile episodes } \\
\text { No difference in severe infections } \\
\text { No difference in antibiotic prescription }\end{array}$ \\
\hline $\begin{array}{l}\text { Sklenar et al. } \\
\text { (30) }\end{array}$ & CLL (31) and MM (31) patients & $\begin{array}{l}\text { Multicentre double-blind, randomized parallel-group } \\
\text { IVlg at } 100,400 \text {, and } 800 \mathrm{mg} / \mathrm{kg} / 21 \text { days }\end{array}$ & $\begin{array}{l}\text { Optimal dose was } 400 \mathrm{mg} / \mathrm{kg} \text { for prevention of bacterial } \\
\text { infections and for increasing pneumococcal antibody } \\
\text { levels }\end{array}$ \\
\hline $\begin{array}{l}\text { Boughton } \\
\text { et al. (6) }\end{array}$ & $\begin{array}{l}\text { CLL patients (42) with } \\
\text { hypogammaglobulinemia and } \\
\text { infections }\end{array}$ & $\begin{array}{l}\text { Randomized parallel-group IVIg } 18 \mathrm{~g} / 21 \text { days versus } \\
\text { placebo and switched to } 24 \mathrm{~g} \text { versus } 18 \mathrm{~g} \text { if } \geq 3 \\
\text { infections }\end{array}$ & $\begin{array}{l}\text { Fewer serious and moderate bacterial infections } \\
50 \% \text { who required dose increase subsequently } \\
\text { infection free } \\
\text { Majority of infections associated with lgG }<3 \mathrm{~g} / \mathrm{L}\end{array}$ \\
\hline
\end{tabular}

CLL, chronic lymphocytic leukemia; MM, multiple myeloma; NHL, non-Hodgkin lymphoma. 
A recommendation, level $1 \mathrm{~b}$ evidence) (4-6, 29-33). Although infections are a major cause of morbidity and mortality in CLL, neither survival benefit nor improvement in quality of life could be demonstrated, which is not surprising given the follow-up period of 1 year $(4,34)$. A recent 14 -year retrospective study in a large series of CLL patients confirmed that hypogammaglobulinemia does not appear to impact overall survival (14). Based on the results of the first controlled trial in a wide range of CLL patients, IVIg was not cost-effective (35). In patients with MM, IVIg for 6-12 months reduced the risk of severe infectious complications (grade A recommendation, level 1b evidence) (31). As a result, IVIg is currently reserved for selected CLL patients with hypogammaglobulinemia and recurrent bacterial infections, especially those in whom prophylactic antibiotics have failed, or with severe infections requiring IV antibiotics or hospitalization and serum IgG levels $<400 \mathrm{mg} / \mathrm{dL}$ (grade $2 \mathrm{~B}$ recommendation, level $1 \mathrm{~A}$ of evidence). Following the original trial, IVIg may be recommended for plateau phase MM patients with hypogammaglobulinemia and recurrent bacterial infections who have failed to respond to pneumococcal immunization $(36,37)$.

However, most of the trial data on which these recommendations are based is over 20 years old. The spectrum of infections has changed in the last decade. Encapsulated bacteria (Streptococcus pneumoniae, Staphylococcus aureus, and Haemophilus influenzae) and herpesviruses remain the most prevalent cause of infections in CLL patients, mainly of the respiratory tract but also the skin, urinary and gastrointestinal tracts, and bloodstream $(9,38,39)$. Additional pathogens of concern vary depending upon the treatment regimen (discussed below).

The original IVIg trial data were done before modern therapies were available. The current guidelines do not take into account the shift in the immune situation of current treatment combinations (40). On the other hand, the above treatment studies were performed without specific antibody testing for patient selection. The use of similar chemotherapeutical protocols in other lymphoproliferative syndromes, mainly indolent non-Hodgkin lymphomas (iNHL) $(41,42)$, suggests that there may be low serum Igs in these patients not previously included in trials (43). This leaves a number of patients without access to IVIg. Regarding $\mathrm{MM}$, although a profound antibody deficit may occur before the plateau phase, and the risk of fungal and viral infections is highest during the first 3 months after diagnosis and therapy, there have been no new trials of infection prevention with IVIg (37). In view of the above, there is a need to re-assess both the level of antibody failure and the role of IVIg on the basis of earlier diagnosis and newer treatment modalities.

\section{SPECIFIC ANTIBODY PRODUCTION RESPONSES IN CLL/MM: IMMUNOLOGICAL EVALUATION AND MONITORING}

\section{Specific Antibody Responses in B-Cell Malignancies}

Not all patients with hypogammaglobulinemia present with infectious complications, so a poor response to pneumococcus was suggested as a good predictor of infections $(13,31)$; furthermore, serious infections can occur in the absence of hypogammaglobulinemia due to other reasons such as neutropenia or T cell suppression. Low baseline levels of specific exposure antibodies against various bacterial, viral, fungal, and protozoan pathogens have been described in these disorders (44). B-cell antimicrobial dysfunction increases progressively from monoclonal gammopathy of undetermined significance (MGUS) to Waldenstrom macroglobulinemia to $\mathrm{MM}(31,44)$. In therapy-naive CLL patients, seroconversion from positive to negative IgG values was noted for EBV- (3.6\%) and, most frequently, for VZV-specific IgG (18\%), while IgG specific for CMV was preserved (45). Significantly, lower responses to vaccination in CLL patients with respect to healthy subjects have been reported against diverse antigens. Specific antibody production to polysaccharide antigens (T-cellindependent response), such as classical 23-valent pneumococcal vaccine (PPV23), is markedly impaired in these patients $(13,31$, 46). Defective response to protein antigens, such as tetanus toxoid and influenza virus, is also apparent $(47,48)$. Interpretation of vaccine responses is complex and requires diverse clinical considerations (49). For the evaluation of primary responses, an increase greater than threefold after 4 weeks with respect to prevaccination levels is considered normal (49). The use of Salmonella typhi Vi vaccine (50) with pure polysaccharide extract may add clinical value in this population.

\section{Immunological Evaluation in B-Cell Malignancy}

To evaluate the role of immunological deficiencies and to monitor patients with hematological malignancy, a complete clinical history of infections is recommended at diagnosis and during follow-up, as well as quantification of serum immunoglobulins (51) and circulating lymphocyte subsets, including CD4 and CD8 T cells as well as B cells (provided the B cell count in CLL is not excessively high) (Table 2). Neutrophil counts should be also regularly monitored.

A recent review by Dhalla et al. (9) has highlighted the relevant role of routine immunological evaluation for secondary specific antibody deficiency to protein and polysaccharide immunizations in CLL as a method for predicting patients prone to infections. These responses should be monitored every 6-12 months and after significant bacterial infections or immunosuppressive therapy, and this approach could be extended to other hematological malignancies.

IgG subclass evaluation could be useful. In a large series of CLL patients, subclass deficiency (particularly IgG3 and IgG1 subclass deficiency) better correlated with recurrent or significant infections than hypogammaglobulinemia itself (100\% of IgG subclass deficiency versus $50 \%$ of hypogammaglobulinemia, respectively) (52). In another study, decreased concentrations of IgG4 and IgG2 were associated with increased susceptibility to infection (17). However, other studies have not shown association between IgG subclass deficiency and infection in CLL (53).

A recent study showed more serious infections in secondary than in primary antibody deficiency patients and similar diagnostic delay and incidence of bronchiectasis (54). For early detection of preventable lung involvement, pulmonary function tests 
TABLE 2 | Initial proposed immunological evaluation in patients with hematological malignancy.

\section{Mandatory}

Detailed medical history. History of recurrent or unusual infections, family history

Complete physical examination, including the skin, all mucous membranes, lymph nodes, spleen, and rectum

CBC with manual differential (presence of anemia, neutropenia, lymphopenia, and thrombocytopenia)

Quantitative $\lg G$, IgA, IgM, and lgE levels

\section{Highly recommended tests}

Isohemagglutinin titers

IgG antibody titers to prior immunizations/exposure

Antibody response to vaccine antigens (e.g., non-conjugated and conjugated

pneumococcal, tetanus, diphtheria, S. typhi, meningococcal antigens,

Haemophilus influenzae b)

$\mathrm{T}$ and $\mathrm{B}$ cell subsets immunophenotyping and absolute counts

\section{Additional tests}

Lung function tests

Thoracic CT

Memory B cell phenotype

Autoantibodies in autoimmune phenomena: antinuclear, anti-DNA,

antiphospholipid, anti-platelet and anti-neutrophil antibodies, cold agglutinins

and high-resolution computerized lung tomography are essential to prevent development and/or progression of bronchiectasis (9). Our strong recommendation is to always consult a clinical immunologist for performing immunological evaluation.

\section{DIAGNOSIS AND THERAPY ISSUES CHALLENGING THE ROLE OF PREVENTION WITH INTRAVENOUS/ SUBCUTANEOUS GAMMAGLOBULINS}

Authorized indications may not be aligned with the current clinical scenario, which stems from diagnostic and therapy changes in hematological malignancies in recent years.

The 2008 revised WHO Classification of Tumours of Haematopoietic and Lymphoid Tissues (55) adopted consensus guidelines for the definition of some well-established diseases, including CLL and MM under the common denomination of mature B-cell neoplasms with other entities. According to this classification, CLL and small lymphocytic lymphoma (SLL) are recognized as different manifestations of a single disease entity (56). Some patients may present solely with lymphadenopathy, organomegaly, and presence of infiltrating monoclonal B cells with the same immunophenotype as CLL cells, but lacking peripheral blood lymphocytosis (57). Moreover, CLL patients are currently being diagnosed earlier in life than was previously the case and the distinction of monoclonal B lymphocytosis (MBL) from CLL is based on practice guidelines of 5,000 lymphocyte counts $/ \mu \mathrm{L}$, as no proven biological parameter can distinguish MBL from CLL or identify which patients will progress to clinically significant disease more rapidly $(58,59)$. It appears that the prevalence of cases that present as "SLL" may be much lower than that of CLL (60). CLL is classified separately as SLL in the International Classification of Diseases (ICD)-10-CM 2015 system (ICD-10).
In the revised 2008 classification, there were no recommendations for changing the definition of recognized categories of MGUS, and regrouped the continuum of smoldering myeloma and indolent myeloma in asymptomatic myeloma. The presence of radiographically detected bone lesions, even if not symptomatic, would exclude a patient from this category, because these are an indication for treatment $(55,56)$. To widen the scope of IVIg use and to favor access for other B-cell malignant neoplasms, the Canadian guidelines of IVIg use in secondary immunodeficiencies established the indication as infection prophylaxis in adults with "malignant hematological disorders" associated with secondary hypogammaglobulinemia and either a recent life-threatening infection, which is thought to be caused by low levels of polyclonal Ig or recurrent episodes of clinically significant infections necessitating the use of antibiotics and which are reasonably thought to be caused by low levels of polyclonal immunoglobulins (23).

\section{Emerging Infections with Novel Therapies}

Current front-line treatment strategies for CLL including combination chemotherapy and biologic agents, such as fludarabine plus cyclophosphamide plus Rtx (FCR) or bendamustine plus Rtx (BR) or alemtuzumab, have greatly improved overall survival, complete response rate and progression-free survival (61-65). However, it has been suggested that these combination regimens increase synergistically myelosuppression and immunosuppression, which comes to the prize of an increased risk of infections $(66,67)$. Severe or unusual infections, with higher rates of global infections compared with the historical group of patients treated with FCalone but without significant influence in infection-related mortality have been reported (62). Particularly, the growing use of Rtx in front-line combination chemotherapy with fludarabine (FCR) increases the risk of all types of infections with respect to Rtx in combination with cyclophosphamide, doxorubicin, vincristine, and prednisone (R-CHOP) or with cyclophosphamide, vincristine, and prednisone (R-CVP) chemotherapy (68). FCR regimen results in a significant myelosuppression and high rates of early and late infections, especially in elderly patients (61). With respect to maintenance therapy, Rtx alone for 2 years after induction therapy was associated with higher rate of all types of infections than the observation alone group (66 versus $50 \%$ ) without influence in infection-related mortality (69). Anti-CD20 monoclonal antibodies have been associated with CMV infections and other virus reactivations (hepatitis $\mathrm{B}$ and polyomavirus JC) $(63,70,71)$. Reactivation of herpes viruses have also been described related to treatment with purine analogs (as Flu) and alemtuzumab (8). With FR combination but also alemtuzumab, opportunistic infections by Pneumocystis, Listeria, mycobacteria, and Candida have become a real concern and occur frequently during the first 3 months of therapy and in previously treated patients $(7,72-74)$. Second- and third-generation anti-CD20 monoclonal antibodies are humanized or fully human antibodies used in CLL and indolent NHL with either higher complementdependent cytotoxicity or antibody-dependent cell-mediated cytotoxicity or direct cytotoxic effects than Rtx (75), but their infections profile in the long-term respect to that of Rtx remain to be explored. Obinutuzumab use for hematological malignancy 
was associated with severe infection in $7 \%$ of patients in a recent clinical trial (76).

The impact of new biologicals for hematological malignancies that inhibit B-cell receptor (BCR) signaling pathway, B cell leukemia/lymphoma-2 (Bcl-2) antagonists, and chimeric antigen receptor (CAR) T cells in terms of long-term infectious complications has not been established. BCR inhibitors' approved to date include the Bruton's tyrosine kinase (BTK) inhibitor ibrutinib; the selective inhibitor of the phosphatidylinositol 3-kinase (PI3K) delta isoform idelalisib; as well as Syk inhibitor fostamatinib disodium (FosD) and SRC family kinases inhibitors (dasatynib, bafetinib). A recent study reports ibrutinib to have a better impact on humoral reconstitution and hence lower infection rates at 12 months (77). However, in a large multicenter, open-label, clinical trial evaluating ibrutinib versus anti-CD20 (ofatumumab) therapy in refractory CLL, severe infections (mainly pneumonia, urinary tract infections, and pyrexia) were similar in both groups (24 versus $22 \%$ of patients), with higher infections in general in the ibrutinib group (70 versus 54\%, respectively), although patients on ibrutinib had longer drug exposure (median, 8.6 versus 5.3 months) and more than 3 months longer adverse event reporting period (78). The rate of severe infections was lower when ibrutinib was given as first-line therapy (4\% pneumonia and $4 \%$ diarrhea) (79). In the clinical trial with idelalisib for refractory CLL reported infections included pneumonia in 6\% and febrile neutropenia in 5\% (80); another clinical trial with idelalisib for indolent refractory NHL included severe neutropenia in $27 \%$ and pneumonia in $7 \%(81)$, while a clinical trial on treatment-naive CLL patients reported $18 \%$ incidence of pneumonia (82). Bcl-2 antagonists, such as venetoclax, have shown in a recent phase II clinical trial in refractory CLL an incidence of pneumonia in 6\% and febrile neutropenia in $5 \%$ of patients (83). In summary, despite promising clinical efficacy and acceptable adverse effects' profiles, these later agents inhibit key molecules in B cell activation and differentiation and also other relevant pathways independent of BCR and neutrophils. Thus, the real clinical extent of the humoral and cellular immune and innate defect of these new agents at the long term, as shown by the primary defects of these molecules $(84,85)$ remains to be determined.

On the other hand, CD19 CAR T cells have been used in relapsed and high-risk CLL with overall response rate of $57 \%$ of 14 patients and persistent B cell aplasia in $100 \%$ of patients with complete remission (CR) and half of the patients with partial remission $(86,87)$. One out of the 4 patients who achieved CR died of an infectious surgery complication almost 2 years after CAR T therapy. Severe hypogammaglobulinemia in these patients was managed with IVIg (86). Interestingly, long-lived plasma cells may account for the persistence of secondary responses to previous exposures (88).

Similar front-line treatment regimens as for CLL (mostly FluR combination) and novel biologic agents are being used in iNHL, mostly in the management of follicular lymphoma (FL), mantlecell lymphoma (MCL), and cases of diffuse large cell lymphoma (DLCL), leading to substantial improvement in prognosis and overall survival (89-92).

The issue of immune hyporesponsiveness during specific intensive chemotherapy is still unexplored. Secondary antibody responses do not seem to be invariably impaired after anti-CD20 monoclonal antibodies, but primary responses, as tested in numerous immunization studies, are clearly impaired $(93,94)$. Rtx has been associated with prolonged hypogammaglobulinemia $(95,96)$ and with neutropenia (even with delayed-onset) (97), although difficult to quantify due to confounding factors, namely, concomitant use of these biologicals with other immunosuppressive or chemotherapeutic agents and the underlying conditions, as well as under-reporting (98). The experience learned from Rtx for autoimmune disease demonstrates that the lower the baseline IgM and IgG levels, the lower post-treatment IgM and IgG levels, the higher infection risk $(96,99)$, with an accumulative effect after repeated cycles (100).

\section{PRACTICAL ISSUES IN THE PREVENTION OF INFECTIOUS COMPLICATIONS}

\section{Vaccination}

Protecting immunocompromised patients against vaccinepreventable infectious diseases is a commonly missed opportunity (101). Although there are no randomized studies showing that vaccination may alter infection rates or outcomes from acquired infections in CLL, routine vaccinations should be maintained in these patients before initiation of treatment if possible $(39,102)$. All live vaccines are contraindicated, including zoster, since severe and even fatal complications have been reported. Diverse studies have shown reasonable rates of seroprotection and seroconversion in various immunocompromised hosts, including oncology patients, with very minimal downside (101). Conjugate vaccines have proved to be highly immunogenic and are to be recommended in these patients $(46,103)$.

Therefore, subunit vaccines against seasonal influenza and against $\mathrm{H} 1 \mathrm{~N} 1$ are broadly recommended across oncologic patient populations, given the severity of the $\mathrm{H} 1 \mathrm{~N} 1$ pandemic and the highly severe flu impact respect to general population despite poor responses in CLL, and even two doses regimen $(48,101,104-107)$.

Streptococcus pneumoniae is the commonest pathogen in hematological malignancy, and invasive disease is significantly higher in MM and more modestly in CLL and NHL. As discussed earlier, although vaccination of seven-valent pneumococcal vaccine show protection to six of the seven antigens in $40 \%$ in series of CLL patients when administered early and prior to therapy (108), there is no data on infection prevention by such immunization in CLL. Despite this, it is now recommended to administer both the 13 -valent and the 23 -valent vaccine $(107,109)$, since $58 \%$ of untreated CLL patients showed a response (103).

A moderate vaccination response rate of $43 \%$ against $H$. influenzae type b (Hib) conjugate vaccine among adult and elderly patients with CLL has been reported (110) but will only protect against type $\mathrm{b} H$. influenzae and not against the much more common infection by the non-encapsulated pathogen. Normal IgG1 and IgA concentrations were associated with protection, while IgM, in turn, was the best predictor of a significant vaccination response. 
Patients receiving intensive chemo- or immunotherapy should be screened for hepatitis $\mathrm{B}$ and $\mathrm{C}$ infection (grade of evidence A1). Hepatitis B vaccine is indicated for patients with CLL who are negative for antibodies against HBsAg; the combined hepatitis $A$ and $B$ vaccine should be considered (111) in endemic regions. The HPV vaccine may be considered for all HPV-seropositive subjects with hematological malignancies, as these malignancies have been associated with high risk of second primary malignancies in general $(112,113)$, and with HPV in particular in a recent study (not only skin cancer but also prostate and colon cancer cells were HPV DNA by PCR) (114).

Given the suboptimal immune responses to immunization of immunocompromised patients, the optimal timing dosing, use of adjuvants, and delivery method might maximize the immunologic benefit of vaccination in oncology patients (101). A potential beneficial strategy could be to vaccinate patients early at diagnosis, for instance at MBL stage, when better responses are attained than CLL (115). The same might be true for MGUS patients at risk of developing MM.

\section{Prophylactic Antibiotics}

The changing spectrum of infections in CLL patients on current therapeutic protocols mandates a newer approach to prophylaxis and therapy. Early recognition of patients susceptible to infection and prophylactic administration of appropriate antibiotics remain the first-line management for symptomatic antibody deficiency in $\operatorname{CLL}(9,21,22)$.

However, clinical trials are lacking (51). In patients with bronchiectasis, nebulized or low dose oral antibiotics, such as azithromycin, can reduce the incidence of recurrent infection. Replacement Ig should be considered if, despite $\mathrm{AB}$ prophylaxis, there are significant breakthrough bacterial infections or if bronchiectasis develops or progresses (51).

Anti-infective prophylaxis is recommended for patients receiving purine-analog and/or alemtuzumab during treatment and thereafter, if tolerated herpes virus (acyclovir or equivalent) and anti-Pneumocystis jirovecii prophylaxis (sulfamethoxazole/ trimethoprim or equivalent) (Grade of evidence IV, B) $(39,51$, $107,116)$. Antivirals are given if the patient is on chemotherapy (FC or FCR) and thus at high risk of opportunistic viral infection. Anti HSV and HZV prophylaxis is recommended in patients requiring intensive and/or immunosuppressive treatment who are seropositive, have a low CD4 count or a history of previous herpes infections (51). The duration of anti-Pneumocystis and herpes prophylaxis is controversial.

Patients on alemtuzumab should be monitored for CMV reactivation (117-119). The current management is controversial; some use ganciclovir (oral or IV) prophylactically if viremia is present, others use ganciclovir only if viral load is rising. CMV viremia should be measured by PCR quantitation at least every 2-3 weeks. Pre-emptive ganciclovir/valganciclovir may be used with CMV viremia or increasing viral load, for 14-21 days until symptoms resolve and PCR tests are negative. Patients' positive for HBSAg or HBCAg may require antiviral treatment and should be managed jointly with a specialist in viral hepatitis (120).

\section{Growth Factors}

The myeloid growth factor, granulocyte colony-stimulating factor (G-CSF) or granulocyte macrophage colony-stimulating factor (GM-CSF), has radically changed the approach to the prevention of febrile neutropenia (121-123). Their use is recommended for the first cycle of chemotherapy for patients with more than a $20 \%$ risk of febrile neutropenia or in case of poor response to antibiotics with persistent neutropenia should lead to the use of these cytokines.

\section{Role of Prophylactic Replacement Immunoglobulin}

Given that therapy of hematological malignancies has substantially changed in the last decade with the introduction of drugs with different modes of action, including monoclonal antibodies, drugs with immunomodulatory effects such as lenalidomide, and targeted drugs such as tyrosine kinase inhibitors, the previous clinical trials may not accurately represent the drawbacks and benefits of IVIg/SCIg now.

Current guidelines state the use of IVIg in severe hypogammaglobulinemia and recurrent infections (Level of evidence I, A) (107). The question of the correct dose of IVIg to prevent bacterial infections is still unresolved and is probably patient dependent $(9,37,124)$. Much has been learnt from the management of patients with PID, such as the use of clinical measures and trough IgG levels to guide dose adjustments and the need to use higher replacement doses in patients with bronchiectasis (124). As a general guideline, maintenance of trough serum IgG in treated patients above $500-700 \mathrm{mg} / \mathrm{dL}$ is a reasonable goal (9).

Treatment should be reconsidered if there is no improvement in the frequency or severity of bacterial infections after 1 year (125). The choices of subcutaneous Ig and self-infusion have reduced costs and improved quality of life $(9,126)$.

The use of IVIg prophylaxis in hematopoietic stem cell transplantation (HSCT) for MM patients without selection by immunological parameters has shown beneficial results in terms of quality of life, but does not seem to affect CMV infection incidence or other infectious complications (127-129).

Expected mechanisms of action of replacement Ig therapy on $\mathrm{B}$ cell cancer include effective reduction in infections by pathogen neutralization, toxin inactivation and opsonization, and complement-mediated bactericidal effects (130). The potential immunomodulatory effects of Ig therapy on the setting of cancer are unclear (131). Ig could induce in vivo beneficial immunomodulatory effects on the malignant B cell clone by several potential mechanisms: inducing unresponsive anergy and subsequent apoptosis in B cells, by inducing proapoptotic molecules expression on tumor cells or by Fas-blocking antibodies in IVIg (132) or through ERK phosphorilation in vitro (133); altering activation and proliferation of B cells $(132,134)$; inhibition of B cell antigen presentation $(135,136)$; in vitro differentiation of B cells and Ig secretion (137); and other immune effects [revised by Corbi et al. (131)].

Increases in the immunodeficiency status of CLL and other hematological malignancies, and growing antibiotic resistant pathogens in what is being called the post-antibiotic era, have 
renewed attention in antibody therapy. In carefully selected patients by clinical infectious history and antibody production defect (9), the criteria for initiating IVIg therapy need to be reassessed in the light of data of PID management to prevent lung damage due to ongoing subclinical infection $(138,139)$. In PID, replacement IVIg therapy is the mainstay of treatment of subjects with antibody failure, and it has revolutionized the lives of these patients (139).

Futures studies should address the question whether in CLL patients requiring long-standing anti-infectious combined protocols with antiviral, antibiotic, and antifungal treatment, IVIg would add a benefit, given the occurrence of pathogens' antibiotic resistance, deleterious effects on microbiota and sideeffects. Also, comparison studies of the impact of IVIg versus antibiotics with current protocols in terms of lung involvement and prognosis are necessary. In the absence of specific studies, recommendations for IVIg replacement in hematological malignancies should be based on clinical experience in PIDs and only in selected individual patients.

\section{POTENTIAL INDICES TO BETTER SELECT PATIENTS FOR WHOM EARLY INTERVENTION WITH IVIg MAY BE BENEFICIAL}

Chronic lymphocytic leukemia is a heterogeneous disease that may evolve as indolent or as an aggressive malignancy. There is a still a lack of biological markers underlying different clinical presentations (57).

We propose the following aspects to be considered in order to improve the rational use of IVIg in indication of B-cell malignancy:

1. Selection of patients for Ig replacement therapy by proven antibody production deficit by routine to protein and polysaccharide immunization protocols: antibody production deficit is a better tool than hypogammaglobulinemia to measure functional dysregulation and to define those patients with hematological malignancy that would benefit from IVIg replacement therapy.

2. Besides, timely Ig replacement therapy can prevent structural lung damage and progression.

3. Immunological monitoring is important to detect patients at risk of severe infections or development or progression of lung damage.

4. On the basis of the currently available indications, the question arises whether we should consider widening the IVIg indication for "hematological malignancy" with recurrent or severe

\section{REFERENCES}

1. Pisciotta AV, Jermain LF, Hinz JE. Chronic lymphocytic leukemia, hypogammaglobulinemia and autoimmune hemolytic anemia - an experiment of nature. Blood (1960) 15:748-57.

2. Rundles RW, Moore JO. Chronic lymphocytic leukemia. Cancer (1978) 42 (2 Suppl):941-5. infections and antibody production defect to other B cell malignancies. This measure may avoid discrimination of patients with of SLL and iNHL with secondary antibody deficiency to CLL and similar chemotherapeutic protocols (140).

5. It would be interesting to ascertain whether immunophenotypic and cytogenetic biomarkers - 17p deletion, ZAP and CD38 expression, and unmutated IgH-, considered as prognostic predictors in terms of overall survival, are associated with more profound immunodeficiency.

6. Assessment of the long-range effects in terms of infectious complications and of immunosuppression of novel agents (i.e., BCR signaling pathway inhibitors and BCL2 antagonists) in combined regimens for indifferent indications (first-line versus repeated cycles) and of CAR T cell therapy.

\section{CONCLUSION}

As better combination regimens with monoclonal antibodies and new biological agents and cell therapies are being developed, a profound immune dysregulation in patients with CLL and other hematological malignancies occurs, which clearly impact on the clinical course of the disease. A potential beneficial strategy could be to vaccinate patients at MBL and MGUS stages (for CLL and MM, respectively) or at the time of B-cell malignancy diagnosis, when better antibody responses are attained. We have to re-emphasize the need for evaluating and monitoring antibody responses to adequately select patients in whom early intervention with prophylactic anti-infective therapy and IVIg is warranted. New clinical trials would be necessary to establish the role of IVIg in hematological malignancy during the combination front-line protocols against antibiotic prophylaxis and to re-evaluate the cost-effectiveness of IVIg in this new scenario.

\section{AUTHOR CONTRIBUTIONS}

SS-R, FD, and HC participated in the conception of the work. SS-R wrote the first draft. FD and HC critical revised and wrote the manuscript.

\section{ACKNOWLEDGMENTS}

SS-R is member of a working group on IDP sponsorized by CSL-Behring and has received speaker fees from Grifols; FD has received a speaker fee from Grifols; $\mathrm{HC}$ is a consultant for Biotest and LFB, and has received a speaker fee from Grifols.

\section{FUNDING}

Grifols provided financial support for the publication fee.

3. Bussel JB, Cunningham-Rundles C. Intravenous usage of gammaglobulin: humoral immunodeficiency, immune thrombocytopenic purpura, and newer indications. Cancer Invest (1985) 3(4):361-6. doi:10.3109/07357908 509039797

4. Intravenous immunoglobulin for the prevention of infection in chronic lymphocytic leukemia. A randomized, controlled clinical trial. Cooperative Group for the Study of Immunoglobulin in Chronic Lymphocytic Leukemia. 
$N \quad$ Engl JMed (1988) 319(14):902-7. doi:10.1056/NEJM198810063 191403

5. Chapel H, Dicato M, Gamm H, Brennan V, Ries F, Bunch C, et al. Immunoglobulin replacement in patients with chronic lymphocytic leukaemia: a comparison of two dose regimes. Br J Haematol (1994) 88(1):209-12. doi:10.1111/j.1365-2141.1994.tb05002.x

6. Boughton BJ, Jackson N, Lim S, Smith N. Randomized trial of intravenous immunoglobulin prophylaxis for patients with chronic lymphocytic leukaemia and secondary hypogammaglobulinaemia. Clin Lab Haematol (1995) 17(1):75-80. doi:10.1111/j.1365-2257.1995.tb00322.x

7. Hamblin AD, Hamblin TJ. The immunodeficiency of chronic lymphocytic leukaemia. Br Med Bull (2008) 87:49-62. doi:10.1093/bmb/ldn034

8. Morrison VA. Infectious complications in patients with chronic lymphocytic leukemia: pathogenesis, spectrum of infection, and approaches to prophylaxis. Clin Lymphoma Myeloma (2009) 9(5):365-70. doi:10.3816/ CLM.2009.n.071

9. Dhalla F, Lucas M, Schuh A, Bhole M, Jain R, Patel SY, et al. Antibody deficiency secondary to chronic lymphocytic leukemia: should patients be treated with prophylactic replacement immunoglobulin? JClin Immunol (2014) 34(3):277-82. doi:10.1007/s10875-014-9995-5

10. Blimark C, Holmberg E, Mellqvist UH, Landgren O, Bjorkholm M, Hultcrantz $\mathrm{M}$, et al. Multiple myeloma and infections: a population-based study on 9253 multiple myeloma patients. Haematologica (2015) 100(1):107-13. doi:10.3324/haematol.2014.107714

11. Nucci $M$, Anaissie E. Infections in patients with multiple myeloma in the era of high-dose therapy and novel agents. Clin Infect Dis (2009) 49(8):1211-25. doi:10.1086/605664

12. O'Brien SN, Blijlevens NM, Mahfouz TH, Anaissie EJ. Infections in patients with hematological cancer: recent developments. Hematology Am Soc Hematol Educ Program (2003) 1:438-72. doi:10.1182/asheducation-2003.1.438

13. Griffiths H, Lea J, Bunch C, Lee M, Chapel H. Predictors of infection in chronic lymphocytic leukaemia (CLL). Clin Exp Immunol (1992) 89(3):374-7. doi:10. 1111/j.1365-2249.1992.tb06965.x

14. Parikh SA, Leis JF, Chaffee KG, Call TG, Hanson CA, Ding W, et al. Hypogammaglobulinemia in newly diagnosed chronic lymphocytic leukemia: natural history, clinical correlates, and outcomes. Cancer (2015) 121(17):2883-91. doi:10.1002/cncr.29518

15. Chiorazzi N, Fu SM, Montazeri G, Kunkel HG, Rai K, Gee T. T cell helper defect in patients with chronic lymphocytic leukemia. JImmunol (1979) 122(3):1087-90.

16. Chapel HM, Bunch C. Mechanisms of infection in chronic lymphocytic leukemia. Semin Hematol (1987) 24(4):291-6.

17. Aittoniemi J, Miettinen A, Laine S, Sinisalo M, Laippala P, Vilpo L, et al. Opsonising immunoglobulins and mannan-binding lectin in chronic lymphocytic leukemia. Leuk Lymphoma (1999) 34(3-4):381-5. doi:10.3109/10428199909050963

18. Foa R, Fierro MT, Lusso P, Raspadori D, Ferrando ML, Matera L, et al. Reduced natural killer T-cells in B-cell chronic lymphocytic leukaemia identified by three monoclonal antibodies: Leu-11, A10, AB8.28. Br J Haematol (1986) 62(1):151-4. doi:10.1111/j.1365-2141.1986.tb02911.x

19. Itala M, Vainio O, Remes K. Functional abnormalities in granulocytes predict susceptibility to bacterial infections in chronic lymphocytic leukaemia. Eur J Haematol (1996) 57(1):46-53. doi:10.1111/j.1600-0609.1996.tb00489.x

20. Jurado-Camino T, Cordoba R, Esteban-Burgos L, Hernandez-Jimenez E, Toledano V, Hernandez-Rivas JA, et al. Chronic lymphocytic leukemia: a paradigm of innate immune cross-tolerance. J Immunol (2015) 194(2):719-27. doi:10.4049/jimmunol.1402272

21. Hensel M, Kornacker M, Yammeni S, Egerer G, Ho AD. Disease activity and pretreatment, rather than hypogammaglobulinaemia, are major risk factors for infectious complications in patients with chronic lymphocytic leukaemia. Br J Haematol (2003) 122(4):600-6. doi:10.1046/j.1365-2141.2003.04497.x

22. Ravandi F, O'Brien S. Immune defects in patients with chronic lymphocytic leukemia. Cancer Immunol Immunother (2006) 55(2):197-209. doi:10.1007/ s00262-005-0015-8

23. Anderson D, Ali K, Blanchette V, Brouwers M, Couban S, Radmoor P, et al. Guidelines on the use of intravenous immune globulin for hematologic conditions. Transfus Med Rev (2007) 21(2 Suppl 1):S9-56. doi:10.1016/j. tmrv.2007.01.001
24. Cantwell M, Hua T, Pappas J, Kipps TJ. Acquired CD40-ligand deficiency in chronic lymphocytic leukemia. Nat Med (1997) 3(9):984-9. doi:10.1038/ nm0997-984

25. Cerutti A, Kim EC, Shah S, Schattner EJ, Zan H, Schaffer A, et al. Dysregulation of $\mathrm{CD} 30+\mathrm{T}$ cells by leukemia impairs isotype switching in normal B cells. Nat Immunol (2001) 2(2):150-6. doi:10.1038/84254

26. Hersey P, Wotherspoon J, Reid G, Gunz FW. Hypogammaglobulinaemia associated with abnormalities of both $\mathrm{B}$ and $\mathrm{T}$ lymphocytes in patients with chronic lymphatic leukaemia. Clin Exp Immunol (1980) 39(3):698-707.

27. Kay NE. Abnormal T-cell subpopulation function in CLL: excessive suppressor ( $\mathrm{T}$ gamma) and deficient helper ( $\mathrm{T} \mathrm{mu}$ ) activity with respect to B-cell proliferation. Blood (1981) 57(3):418-20.

28. Sampalo A, Brieva JA. Humoral immunodeficiency in chronic lymphocytic leukemia: role of CD95/CD95L in tumoral damage and escape. Leuk Lymphoma (2002) 43(4):881-4. doi:10.1080/10428190290017033

29. Griffiths H, Brennan V, Lea J, Bunch C, Lee M, Chapel H. Crossover study of immunoglobulin replacement therapy in patients with low-grade B-cell tumors. Blood (1989) 73(2):366-8.

30. Sklenar I, Schiffman G, Jonsson V, Verhoef G, Birgens H, Boogaerts M, et al. Effect of various doses of intravenous polyclonal IgG on in vivo levels of 12 pneumococcal antibodies in patients with chronic lymphocytic leukaemia and multiple myeloma. Oncology (1993) 50(6):466-77. doi:10.1159/ 000227231

31. Chapel HM, Lee M, Hargreaves R, Pamphilon DH, Prentice AG. Randomised trial of intravenous immunoglobulin as prophylaxis against infection in plateau-phase multiple myeloma. The UK Group for Immunoglobulin Replacement Therapy in Multiple Myeloma. Lancet (1994) 343(8905): 1059-63. doi:10.1016/S0140-6736(94)90180-5

32. Jurlander J, Geisler CH, Hansen MM. Treatment of hypogammaglobulinaemia in chronic lymphocytic leukaemia by low-dose intravenous gammaglobulin. Eur J Haematol (1994) 53(2):114-8. doi:10.1111/j.1600-0609.1994. tb01874.x

33. Molica S, Musto P, Chiurazzi F, Specchia G, Brugiatelli M, Cicoira L, et al. Prophylaxis against infections with low-dose intravenous immunoglobulins (IVIg) in chronic lymphocytic leukemia. Results of a crossover study. Haematologica (1996) 81(2):121-6.

34. Raanani P, Gafter-Gvili A, Paul M, Ben-Bassat I, Leibovici L, Shpilberg O. Immunoglobulin prophylaxis in chronic lymphocytic leukemia and multiple myeloma: systematic review and meta-analysis. Leuk Lymphoma (2009) 50(5):764-72. doi:10.1080/10428190902856824

35. Weeks JC, Tierney MR, Weinstein MC. Cost effectiveness of prophylactic intravenous immune globulin in chronic lymphocytic leukemia. $N$ Engl J Med (1991) 325(2):81-6. doi:10.1056/NEJM199107113250202

36. Gamm H, Huber C, Chapel H, Lee M, Ries F, Dicato MA. Intravenous immune globulin in chronic lymphocytic leukaemia. Clin Exp Immunol (1994) 97(Suppl 1):17-20.

37. EMEA. Report of EMEA Expert Meeting on the Revision of the Core SPC and Note for Guidance for Human Normal Immunoglobulin for Intravenous Administration (IVIg). London: European Medicines Agency (2008). p. 1-40. EMEA/CHMP/BPWP/361857/2006. Available from: http://www.emea. europa.eu/pdfs/human/bpwg/36185706en.pdf

38. Itala M, Helenius H, Nikoskelainen J, Remes K. Infections and serum IgG levels in patients with chronic lymphocytic leukemia. Eur J Haematol (1992) 48(5):266-70. doi:10.1111/j.1600-0609.1992.tb01805.x

39. Young JA. Epidemiology and management of infectious complications of contemporary management of chronic leukemias. Infect Disord Drug Targets (2011) 11(1):3-10. doi:10.2174/187152611794407755

40. Cabanillas F, Liboy I, Pavia O, Rivera E. High incidence of non-neutropenic infections induced by rituximab plus fludarabine and associated with hypogammaglobulinemia: a frequently unrecognized and easily treatable complication. Ann Oncol (2006) 17(9):1424-7. doi:10.1093/annonc/ mdl141

41. Nishio M, Fujimoto K, Yamamoto S, Endo T, Sakai T, Obara M, et al. Delayed redistribution of $\mathrm{CD} 27, \mathrm{CD} 40$ and $\mathrm{CD} 80$ positive $\mathrm{B}$ cells and the impaired in vitro immunoglobulin production in patients with non-Hodgkin lymphoma after rituximab treatment as an adjuvant to autologous stem cell transplantation. Br J Haematol (2007) 137(4):349-54. doi:10.1111/ j.1365-2141.2007.06584.x 
42. Walker AR, Kleiner A, Rich L, Conners C, Fisher RI, Anolik J, et al. Profound hypogammaglobulinemia 7 years after treatment for indolent lymphoma. Cancer Invest (2008) 26(4):431-3. doi:10.1080/07357900701809068

43. Casulo C, Maragulia J, Zelenetz AD. Incidence of hypogammaglobulinemia in patients receiving rituximab and the use of intravenous immunoglobulin for recurrent infections. Clin Lymphoma Myeloma Leuk (2013) 13(2):106-11. doi:10.1016/j.clml.2012.11.011

44. Karlsson J, Andreasson B, Kondori N, Erman E, Riesbeck K, Hogevik H, et al. Comparative study of immune status to infectious agents in elderly patients with multiple myeloma, Waldenstrom's macroglobulinemia, and monoclonal gammopathy of undetermined significance. Clin Vaccine Immunol (2011) 18(6):969-77. doi:10.1128/CVI.00021-11

45. Vanura K, Rieder F, Kastner MT, Biebl J, Sandhofer M, Le T, et al. Chronic lymphocytic leukemia patients have a preserved cytomegalovirus-specific antibody response despite progressive hypogammaglobulinemia. PLoS One (2013) 8(10):e78925. doi:10.1371/journal.pone.0078925

46. Sinisalo M, Aittoniemi J, Oivanen P, Kayhty H, Olander RM, Vilpo J. Response to vaccination against different types of antigens in patients with chronic lymphocytic leukaemia. Br J Haematol (2001) 114(1):107-10. doi:10.1046/j.1365-2141.2001.02882.x

47. Sinisalo M, Aittoniemi J, Kayhty H, Vilpo J. Vaccination against infections in chronic lymphocytic leukemia. Leuk Lymphoma (2003) 44(4):649-52. doi:10.1080/1042819031000063408

48. Pollyea DA, Brown JM, Horning SJ. Utility of influenza vaccination for oncology patients. JClin Oncol (2010) 28(14):2481-90. doi:10.1200/ JCO.2009.26.6908

49. Orange JS, Ballow M, Stiehm ER, Ballas ZK, Chinen J, De La Morena M, et al. Use and interpretation of diagnostic vaccination in primary immunodeficiency: a working group report of the Basic and Clinical Immunology Interest Section of the American Academy of Allergy, Asthma \& Immunology. J Allergy Clin Immunol (2012) 130(3 Suppl):S1-24. doi:10.1016/j.jaci.2012.07.002

50. Ferry BL, Misbah SA, Stephens P, Sherrell Z, Lythgoe H, Bateman E, et al. Development of an anti-Salmonella typhi Vi ELISA: assessment of immunocompetence in healthy donors. Clin Exp Immunol (2004) 136(2):297-303. doi:10.1111/j.1365-2249.2004.02439.x

51. Oscier D, Dearden C, Eren E, Fegan C, Follows G, Hillmen P, et al. Guidelines on the diagnosis, investigation and management of chronic lymphocytic leukaemia. Br J Haematol (2012) 159(5):541-64. doi:10.1111/bjh.12067

52. Freeman JA, Crassini KR, Best OG, Forsyth CJ, Mackinlay NJ, Han P, et al. Immunoglobulin $\mathrm{G}$ subclass deficiency and infection risk in 150 patients with chronic lymphocytic leukemia. Leuk Lymphoma (2013) 54(1):99-104. doi:10.3109/10428194.2012.706285

53. Svensson T, Hoglund $M$, Cherif $H$. Clinical significance of serum immunoglobulin $\mathrm{G}$ subclass deficiency in patients with chronic lymphocytic leukemia. Scand J Infect Dis (2013) 45(7):537-42. doi:10.3109/00365548.20 13.809623

54. Duraisingham SS, Buckland M, Dempster J, Lorenzo L, Grigoriadou S, Longhurst HJ. Primary vs. secondary antibody deficiency: clinical features and infection outcomes of immunoglobulin replacement. PLoS One (2014) 9(6):e100324. doi:10.1371/journal.pone.0100324

55. Swerdlow SH, Campo E, Harris NL, Jaffe ES, Pileri SA, Stein H, et al. WHO Classification of Tumours of Haematopoietic and Lymphoid Tissues. (2008) Lyon: IARC Press.

56. Campo E, Swerdlow SH, Harris NL, Pileri S, Stein H, Jaffe ES. The 2008 WHO classification of lymphoid neoplasms and beyond: evolving concepts and practical applications. Blood (2011) 117(19):5019-32. doi:10.1182/ blood-2011-01-293050

57. Santos FP, O’Brien S. Small lymphocytic lymphoma and chronic lymphocytic leukemia: are they the same disease? Cancer J (2012) 18(5):396-403. doi:10.1097/PPO.0b013e31826cda2d

58. Rawstron AC, Bennett FL, O'Connor SJ, Kwok M, Fenton JA, Plummer M, et al. Monoclonal B-cell lymphocytosis and chronic lymphocytic leukemia. N Engl J Med (2008) 359(6):575-83. doi:10.1056/NEJMoa075290

59. Landgren O, Albitar M, Ma W, Abbasi F, Hayes RB, Ghia P, et al. B-cell clones as early markers for chronic lymphocytic leukemia. N Engl J Med (2009) 360(7):659-67. doi:10.1056/NEJMoa0806122

60. Dores GM, Anderson WF, Curtis RE, Landgren O, Ostroumova E, Bluhm EC, et al. Chronic lymphocytic leukaemia and small lymphocytic lymphoma: overview of the descriptive epidemiology. Br J Haematol (2007) 139(5): 809-19. doi:10.1111/j.1365-2141.2007.06856.x

61. Hallek M, Fischer K, Fingerle-Rowson G, Fink AM, Busch R, Mayer J, et al. Addition of rituximab to fludarabine and cyclophosphamide in patients with chronic lymphocytic leukaemia: a randomised, open-label, phase 3 trial. Lancet (2010) 376(9747):1164-74. doi:10.1016/S0140-6736(10) 61381-5

62. Bauer K, Rancea M, Roloff V, Elter T, Hallek M, Engert A, et al. Rituximab, ofatumumab and other monoclonal anti-CD20 antibodies for chronic lymphocytic leukaemia. Cochrane Database Syst Rev (2012) 11:CD008079. doi:10.1002/14651858.CD008079.pub2

63. Skoetz N, Bauer K, Elter T, Monsef I, Roloff V, Hallek M, et al. Alemtuzumab for patients with chronic lymphocytic leukaemia. Cochrane Database Syst Rev (2012) 2:CD008078. doi:10.1002/14651858.CD008078.pub2

64. Cramer P, Langerbeins P, Eichhorst B, Hallek M. Advances in first-line treatment of chronic lymphocytic leukemia: current recommendations on management and first-line treatment by the German CLL Study Group (GCLLSG). Eur J Haematol (2016) 96(1):9-18. doi:10.1111/ejh.12678

65. Rai KR. Therapeutic potential of new B cell-targeted agents in the treatment of elderly and unfit patients with chronic lymphocytic leukemia. J Hematol Oncol (2015) 8:85. doi:10.1097/00043426-198608010-00019

66. Besada E, Bader L, Nossent H. Sustained hypogammaglobulinemia under rituximab maintenance therapy could increase the risk for serious infections: a report of two cases. Rheumatol Int (2013) 33(6):1643-4. doi:10.1007/ s00296-012-2483-4

67. Visco C, Finotto S, Pomponi F, Sartori R, Laveder F, Trentin L, et al. The combination of rituximab, bendamustine, and cytarabine for heavily pretreated relapsed/refractory cytogenetically high-risk patients with chronic lymphocytic leukemia. Am J Hematol (2013) 88(4):289-93. doi:10.1002/ ajh.23396

68. De Angelis F, Tosti ME, Capria S, Russo E, D’Elia GM, Annechini G, et al. Risk of secondary hypogammaglobulinaemia after rituximab and fludarabine in indolent non-Hodgkin lymphomas: a retrospective cohort study. Leuk Res (2015) 39(12):1382-8. doi:10.1016/j.leukres.2015.10.013

69. Greil R, Obrtlikova P, Smolej L, Kozak T, Steurer M, Andel J, et al. Rituximab maintenance versus observation alone in patients with chronic lymphocytic leukaemia who respond to first-line or second-line rituximab-containing chemoimmunotherapy: final results of the AGMT CLL-8a Mabtenance randomised trial. Lancet Haematol (2016) 3(7):e317-29. doi:10.1016/ S2352-3026(16)30045-X

70. Tuccori M, Focosi D, Blandizzi C, Pelosini M, Montagnani S, Maggi F, et al. Inclusion of rituximab in treatment protocols for non-Hodgkin's lymphomas and risk for progressive multifocal leukoencephalopathy. Oncologist (2010) 15(11):1214-9. doi:10.1634/theoncologist.2010-0098

71. Ozoya OO, Sokol L, Dalia S. Hepatitis B reactivation with novel agents in non-Hodgkin's lymphoma and prevention strategies. JClin Transl Hepatol (2016) 4(2):143-50. doi:10.14218/JCTH.2016.00005

72. Keating MJ, O’Brien S, Albitar M, Lerner S, Plunkett W, Giles F, et al. Early results of a chemoimmunotherapy regimen of fludarabine, cyclophosphamide, and rituximab as initial therapy for chronic lymphocytic leukemia. J Clin Oncol (2005) 23(18):4079-88. doi:10.1200/JCO.2005.12.051

73. Wadhwa PD, Morrison VA. Infectious complications of chronic lymphocytic leukemia. Semin Oncol (2006) 33(2):240-9. doi:10.1053/j. seminoncol.2005.12.013

74. Jiang X, Mei X, Feng D, Wang X. Prophylaxis and treatment of Pneumocystis jirovecii pneumonia in lymphoma patients subjected to rituximabcontained therapy: a systemic review and meta-analysis. PLoS One (2015) 10(4):e0122171. doi:10.1371/journal.pone.0116010

75. Polito L, Bortolotti M, Maiello S, Battelli MG, Bolognesi A. Rituximab and other new anti-CD20 MABs for non-Hodgkin's lymphoma treatment. EMJ Oncol (2014) 2:63-9.

76. Shah A. New developments in the treatment of chronic lymphocytic leukemia: role of obinutuzumab. Ther Clin Risk Manag (2015) 11:1113-22. doi:10.2147/TCRM.S71839

77. Sun C, Tian X, Lee YS, Gunti S, Lipsky A, Herman SE, et al. Partial reconstitution of humoral immunity and fewer infections in patients with chronic lymphocytic leukemia treated with ibrutinib. Blood (2015) 126(19):2213-9. doi:10.1182/blood-2015-04-639203 
78. Byrd JC, Harrington B, O'Brien S, Jones JA, Schuh A, Devereux S, et al. Acalabrutinib (ACP-196) in relapsed chronic lymphocytic leukemia. $N$ Engl J Med (2016) 374(4):323-32. doi:10.1056/NEJMoa1509981

79. Burger JA, Tedeschi A, Barr PM, Robak T, Owen C, Ghia P, et al. Ibrutinib as initial therapy for patients with chronic lymphocytic leukemia. $N$ Engl J Med (2015) 373(25):2425-37. doi:10.1056/NEJMoa1509388

80. Furman RR, Sharman JP, Coutre SE, Cheson BD, Pagel JM, Hillmen P, et al. Idelalisib and rituximab in relapsed chronic lymphocytic leukemia. $N$ Engl J Med (2014) 370(11):997-1007. doi:10.1056/NEJMoa1315226

81. Gopal AK, Kahl BS, de Vos S, Wagner-Johnston ND, Schuster SJ, Jurczak WJ, et al. PI3Kdelta inhibition by idelalisib in patients with relapsed indolent lymphoma. N Engl J Med (2014) 370(11):1008-18. doi:10.1056/ NEJMoal314583

82. O’Brien SM, Lamanna N, Kipps TJ, Flinn I, Zelenetz AD, Burger JA, et al. A phase 2 study of idelalisib plus rituximab in treatment-naive older patients with chronic lymphocytic leukemia. Blood (2015) 126(25):2686-94. doi:10.1182/blood-2015-03-630947

83. Stilgenbauer S, Eichhorst B, Schetelig J, Coutre S, Seymour JF, Munir T, et al. Venetoclax in relapsed or refractory chronic lymphocytic leukaemia with 17p deletion: a multicentre, open-label, phase 2 study. Lancet Oncol (2016) 17(6):768-78. doi:10.1016/S1470-2045(16)30019-5

84. Durandy A, Kracker S, Fischer A. Primary antibody deficiencies. Nat Rev Immunol (2013) 13(7):519-33. doi:10.1038/nri3466

85. Perez de Diego R, Sanchez-Ramon S, Lopez-Collazo E, MartinezBarricarte R, Cubillos-Zapata C, Ferreira Cerdan A, et al. Genetic errors of the human caspase recruitment domain-B-cell lymphoma 10-mucosaassociated lymphoid tissue lymphoma-translocation gene $1(\mathrm{CBM})$ complex: molecular, immunologic, and clinical heterogeneity. J Allergy Clin Immunol (2015) 136(5):1139-49. doi:10.1016/j.jaci.2015.06.031

86. Porter DL, Hwang WT, Frey NV, Lacey SF, Shaw PA, Loren AW, et al. Chimeric antigen receptor $\mathrm{T}$ cells persist and induce sustained remissions in relapsed refractory chronic lymphocytic leukemia. Sci Transl Med (2015) 7(303):303ra139. doi:10.1126/scitranslmed.aac5415

87. Singh N, Frey NV, Grupp SA, Maude SL. CAR T cell therapy in acute lymphoblastic leukemia and potential for chronic lymphocytic leukemia. Curr Treat Options Oncol (2016) 17(6):28. doi:10.1007/s11864-016-0406-4

88. Bhoj VG, Arhontoulis D, Wertheim G, Capobianchi J, Callahan CA, Ellebrecht CT, et al. Persistence of long-lived plasma cells and humoral immunity in individuals responding to CD19-directed CAR T cell therapy. Blood (2016) 128(3):360-70. doi:10.1182/blood-2016-01-694356

89. Foran JM. Antibody-based therapy of non-Hodgkin's lymphoma. Best Pract Res Clin Haematol (2002) 15(3):449-65. doi:10.1053/beha.2002.0222

90. Friedberg JW, Vose JM, Kelly JL, Young F, Bernstein SH, Peterson D, et al. The combination of bendamustine, bortezomib, and rituximab for patients with relapsed/refractory indolent and mantle cell non-Hodgkin lymphoma. Blood (2011) 117(10):2807-12. doi:10.1182/blood-2011-03-340307

91. Hua Q, Zhu Y, Liu H. Severe and fatal adverse events risk associated with rituximab addition to B-cell non-Hodgkin's lymphoma (B-NHL) chemotherapy: a meta-analysis. J Chemother (2015) 27(6):365-70. doi:10.1179/197394 7815Y.0000000025

92. Weide R, Feiten S, Friesenhahn V, Heymanns J, Kleboth K, Thomalla J, et al. [Immunoglobulin substitution in patients with indolent non-Hodgkin's lymphoma]. Dtsch Med Wochenschr (2015) 140(19):e201-6. doi:10.1055/ s-0041-102631

93. Pescovitz MD, Torgerson TR, Ochs HD, Ocheltree E, McGee P, KrauseSteinrauf $\mathrm{H}$, et al. Effect of rituximab on human in vivo antibody immune responses. J Allergy Clin Immunol (2011) 128(6):1295-1302e1295. doi:10.1016/j.jaci.2011.08.008

94. Cambridge G, Perry HC, Nogueira L, Serre G, Parsons HM, De La Torre I, et al. The effect of B-cell depletion therapy on serological evidence of B-cell and plasmablast activation in patients with rheumatoid arthritis over multiple cycles of rituximab treatment. J Autoimmun (2014) 50:67-76. doi:10.1016/j. jaut.2013.12.002

95. Irie E, Shirota Y, Suzuki C, Tajima Y, Ishizawa K, Kameoka J, et al. Severe hypogammaglobulinemia persisting for 6 years after treatment with rituximab combined chemotherapy due to arrest of B lymphocyte differentiation together with alteration of T lymphocyte homeostasis. Int J Hematol (2010) 91(3):501-8. doi:10.1007/s12185-010-0528-6
96. Roberts DM, Jones RB, Smith RM, Alberici F, Kumaratne DS, Burns S, et al. Rituximab-associated hypogammaglobulinemia: incidence, predictors and outcomes in patients with multi-system autoimmune disease. J Autoimmun (2015) 57:60-5. doi:10.1016/j.jaut.2014.11.004

97. Cattaneo C, Spedini P, Casari S, Re A, Tucci A, Borlenghi E, et al. Delayedonset peripheral blood cytopenia after rituximab: frequency and risk factor assessment in a consecutive series of 77 treatments. Leuk Lymphoma (2006) 47(6):1013-7. doi:10.1080/10428190500473113

98. Gea-Banacloche JC. Rituximab-associated infections. Semin Hematol (2010) 47(2):187-98. doi:10.1053/j.seminhematol.2010.01.002

99. Gottenberg JE, Ravaud P, Bardin T, Cacoub P, Cantagrel A, Combe B, et al. Risk factors for severe infections in patients with rheumatoid arthritis treated with rituximab in the autoimmunity and rituximab registry. Arthritis Rheum (2010) 62(9):2625-32. doi:10.1002/art.27555

100. De La Torre I, Leandro MJ, Valor L, Becerra E, Edwards JC, Cambridge G. Total serum immunoglobulin levels in patients with RA after multiple B-cell depletion cycles based on rituximab: relationship with B-cell kinetics. Rheumatology (Oxford) (2012) 51(5):833-40. doi:10.1093/rheumatology/ ker417

101. Kotton CN, Poznanski MC. Vaccination of oncology patients: an effective tool and an opportunity not to be missed. Oncologist (2012) 17(1):1-2. doi:10.1634/theoncologist.2011-0383

102. Tsigrelis C, Ljungman P. Vaccinations in patients with hematological malignancies. Blood Rev (2016) 30(2):139-47. doi:10.1016/j.blre.2015.10.001

103. Pasiarski M, Rolinski J, Grywalska E, Stelmach-Goldys A, KoronaGlowniak I, Gozdz S, et al. Antibody and plasmablast response to 13-valent pneumococcal conjugate vaccine in chronic lymphocytic leukemia patients preliminary report. PLoS One (2014) 9(12):e114966. doi:10.1371/journal. pone.0114966

104. van der Velden AM, Mulder AH, Hartkamp A, Diepersloot RJ, van VelzenBlad H, Biesma DH. Influenza virus vaccination and booster in B-cell chronic lymphocytic leukaemia patients. Eur J Intern Med (2001) 12(5):420-4. doi:10.1016/S0953-6205(01)00149-2

105. de Lavallade H, Garland P, Sekine T, Hoschler K, Marin D, Stringaris K, et al. Repeated vaccination is required to optimize seroprotection against H1N1 in the immunocompromised host. Haematologica (2011) 96(2):307-14. doi:10.3324/haematol.2010.032664

106. Vinograd I, Baslo R, Eliakim-Raz N, Farbman L, Taha A, Sakhnini A, et al. Factors associated with influenza vaccination among adult cancer patients: a case-control study. Clin Microbiol Infect (2014) 20(9):899-905. doi:10.1111/1469-0691.12625

107. Eichhorst B, Robak T, Montserrat E, Ghia P, Hillmen P, Hallek M, et al. Chronic lymphocytic leukaemia: ESMO Clinical Practice Guidelines for diagnosis, treatment and follow-up. Ann Oncol (2015) 26(Suppl 5):v78-84. doi:10.1093/annonc/mdv233.265

108. Sinisalo M, Vilpo J, Itala M, Vakevainen M, Taurio J, Aittoniemi J. Efficacy of pneumococcal vaccination on chronic lymphocytic leukemia: should we rely on surrogate markers? Vaccine (2008) 26(32):3959. doi:10.1016/j. vaccine.2008.04.063

109. Wong A, Marrie TJ, Garg S, Kellner JD, Tyrrell GJ, Group S. Increased risk of invasive pneumococcal disease in haematological and solid-organ malignancies. Epidemiol Infect (2010) 138(12):1804-10. doi:10.1017/ S0950268809991555

110. Sinsalo M, Aittoniemi J, Kayhty H, Vilpo J. Haemophilus influenzae type b (Hib) antibody concentrations and vaccination responses in patients with chronic lymphocytic leukaemia: predicting factors for response. Leuk Lymphoma (2002) 43(10):1967-9. doi:10.1080/1042819021000015916

111. Brenol CV, da Mota LM, Cruz BA, Pileggi GS, Pereira IA, Rezende LS, et al. 2012 Brazilian Society of Rheumatology Consensus on vaccination of patients with rheumatoid arthritis. Rev Bras Reumatol (2013) 53(1):4-23. doi:10.1016/S2255-5021(13)70002-6

112. Santoro A, Rilke F, Franchi F, Monfardini S. Primary malignant neoplasms associated with chronic lymphocytic leukemia. Tumori (1980) 66(4):431-7.

113. Brewer JD, Shanafelt TD, Khezri F, Sosa Seda IM, Zubair AS, Baum CL, et al. Increased incidence and recurrence rates of nonmelanoma skin cancer in patients with non-Hodgkin lymphoma: a Rochester epidemiology project population-based study in Minnesota. J Am Acad Dermatol (2015) 72(2):302-9. doi:10.1016/j.jaad.2014.10.028 
114. Flynn JM, Andritsos L, Lucas D, Byrd JC. Second malignancies in B-cell chronic lymphocytic leukaemia: possible association with human papilloma virus. Br J Haematol (2010) 149(3):388-90. doi:10.1111/j.1365-2141. 2010.08110.x

115. Whitaker JA, Shanafelt TD, Poland GA, Kay NE. Room for improvement: immunizations for patients with monoclonal B-cell lymphocytosis or chronic lymphocytic leukemia. Clin Adv Hematol Oncol (2014) 12(7):440-50. doi:10.1038/leu.2012.187

116. Obeid KM, Aguilar J, Szpunar S, Sharma M, del Busto R, Al-Katib A, et al. Risk factors for Pneumocystis jirovecii pneumonia in patients with lymphoproliferative disorders. Clin Lymphoma Myeloma Leuk (2012) 12(1):66-9. doi:10.1016/j.clml.2011.07.006

117. Elter T, Vehreschild JJ, Gribben J, Cornely OA, Engert A, Hallek M. Management of infections in patients with chronic lymphocytic leukemia treated with alemtuzumab. Ann Hematol (2009) 88(2):121-32. doi:10.1007/ s00277-008-0566-9

118. O'Brien SM, Keating MJ, Mocarski ES. Updated guidelines on the management of cytomegalovirus reactivation in patients with chronic lymphocytic leukemia treated with alemtuzumab. Clin Lymphoma Myeloma (2006) $7(2): 125-30$.

119. Osterborg A, Foà R, Bezares RF, Dearden C, Dyer MJ, Geisler C, et al. Management guidelines for the use of alemtuzumab in chronic lymphocytic leukemia. Leukemia (2009) 23(11):1980-8. doi:10.1038/leu. 2009.146

120. Artz AS, Somerfield MR, Feld JJ, Giusti AF, Kramer BS, Sabichi AL, et al. American Society of Clinical Oncology provisional clinical opinion: chronic hepatitis B virus infection screening in patients receiving cytotoxic chemotherapy for treatment of malignant diseases. J Clin Oncol (2010) 28(19):3199-202. doi:10.1200/JCO.2010.30.0673

121. Lyman GH. Risks and consequences of chemotherapy-induced neutropenia. Clin Cornerstone (2006) 8(Suppl 5):S12-8. doi:10.1016/S1098-3597(06) 80054-2

122. Smith TJ, Khatcheressian J, Lyman GH, Ozer H, Armitage JO, Balducci L, et al. 2006 update of recommendations for the use of white blood cell growth factors: an evidence-based clinical practice guideline. J Clin Oncol (2006) 24(19):3187-205. doi:10.1200/JCO.2006.06.4451

123. Dale DC. Advances in the treatment of neutropenia. Curr Opin Support Palliat Care (2009) 3(3):207-12. doi:10.1097/SPC.0b013e32832ea6ae

124. Lucas M, Lee M, Lortan J, Lopez-Granados E, Misbah S, Chapel H. Infection outcomes in patients with common variable immunodeficiency disorders: relationship to immunoglobulin therapy over 22 years. J Allergy Clin Immunol (2010) 125(6):1354-1360e1354. doi:10.1016/j.jaci.2010.02.040

125. Provan D, Chapel HM, Sewell WA, O'Shaughnessy D; UK Immunoglobulin Expert Working Group. Prescribing intravenous immunoglobulin: summary of Department of Health guidelines. BMJ (2008) 337:a1831. doi:10.1136/ bmj.a1831

126. Nicolay U, Kiessling P, Berger M, Gupta S, Yel L, Roifman CM, et al. Health-related quality of life and treatment satisfaction in North American patients with primary immunedeficiency diseases receiving subcutaneous IgG self-infusions at home. J Clin Immunol (2006) 26(1):65-72. doi:10.1007/ s10875-006-8905-x

127. Blombery P, Prince HM, Worth LJ, Main J, Yang M, Wood EM, et al. Prophylactic intravenous immunoglobulin during autologous haemopoietic stem cell transplantation for multiple myeloma is not associated with reduced infectious complications. Ann Hematol (2011) 90(10):1167-72. doi:10.1007/ s00277-011-1275-3

128. Ichihara H, Nakamae H, Hirose A, Nakane T, Koh H, Hayashi Y, et al. Immunoglobulin prophylaxis against cytomegalovirus infection in patients at high risk of infection following allogeneic hematopoietic cell transplantation. Transplant Proc (2011) 43(10):3927-32. doi:10.1016/j. transproceed.2011.08.104

129. Khalafallah A, McDonnell K, Dawar HU, Robertson I, Woods D. Quality of life assessment in multiple myeloma patients undergoing dose-reduced tandem autologous stem cell transplantation. Mediterr J Hematol Infect Dis (2011) 3(1):e2011057. doi:10.4084/mjhid.2011.057

130. Kaveri SV, Maddur MS, Hegde P, Lacroix-Desmazes S, Bayry J. Intravenous immunoglobulins in immunodeficiencies: more than mere replacement therapy. Clin Exp Immunol (2011) 164(Suppl 2):2-5. doi:10.1111/j.1365-2249. 2011.04387.x

131. Corbi AL, Sanchez-Ramon S, Dominguez-Soto A. The potential of intravenous immunoglobulins for cancer therapy: a road that is worth taking? Immunotherapy (2016) 8(5):601-12. doi:10.2217/imt.16.9

132. Prasad NK, Papoff G, Zeuner A, Bonnin E, Kazatchkine MD, Ruberti G, et al. Therapeutic preparations of normal polyspecific IgG (IVIg) induce apoptosis in human lymphocytes and monocytes: a novel mechanism of action of IVIg involving the Fas apoptotic pathway. J Immunol (1998) 161(7): 3781-90.

133. Mitrevski M, Marrapodi R, Camponeschi A, Cavaliere FM, Lazzeri C, Todi L, et al. Intravenous immunoglobulin and immunomodulation of B-cell - in vitro and in vivo effects. Front Immunol (2015) 6:4. doi:10.3389/ fimmu.2015.00004

134. Besa EC. Use of intravenous immunoglobulin in chronic lymphocytic leukemia. Am J Med (1984) 76(3A):209-18. doi:10.1016/0002-9343(84)90344-9

135. Paquin-Proulx D, Aubin E, Lemieux R, Bazin R. Inhibition of B cell-mediated antigen presentation by intravenous immunoglobulins (IVIg). Clin Immunol (2010) 135(3):422-9. doi:10.1016/j.clim.2010.01.001

136. Paquin-Proulx D, Sandberg JK. Persistent immune activation in CVID and the role of IVIg in its suppression. Front Immunol (2014) 5:637. doi:10.3389/ fimmu.2014.00637

137. Bayry J, Fournier EM, Maddur MS, Vani J, Wootla B, Siberil S, et al. Intravenous immunoglobulin induces proliferation and immunoglobulin synthesis from B cells of patients with common variable immunodeficiency: a mechanism underlying the beneficial effect of IVIg in primary immunodeficiencies. J Autoimmun (2011) 36(1):9-15. doi:10.1016/j.jaut.2010. 09.006

138. Chapel H, Cunningham-Rundles C. Update in understanding common variable immunodeficiency disorders (CVIDs) and the management of patients with these conditions. Br J Haematol (2009) 145(6):709-27. doi:10.1111/j.1365-2141.2009.07669.x

139. Cunningham-Rundles C. Lung disease, antibodies and other unresolved issues in immune globulin therapy for antibody deficiency. Clin Exp Immunol (2009) 157(Suppl 1):12-6. doi:10.1111/j.1365-2249.2009.03952.x

140. Zelenetz AD, Gordon LI, Wierda WG, Abramson JS, Advani RH, Andreadis $\mathrm{CB}$, et al. National comprehensive cancer network. Non-Hodgkin's lymphomas, version 4.2014. J Natl Compr Canc Netw (2014) 12(9):1282-303.

Conflict of Interest Statement: The authors declare that the research was conducted in the absence of any commercial or financial relationships that could be construed as a potential conflict of interest.

Copyright (C) 2016 Sánchez-Ramón, Dhalla and Chapel. This is an open-access article distributed under the terms of the Creative Commons Attribution License (CC BY). The use, distribution or reproduction in other forums is permitted, provided the original author(s) or licensor are credited and that the original publication in this journal is cited, in accordance with accepted academic practice. No use, distribution or reproduction is permitted which does not comply with these terms. 